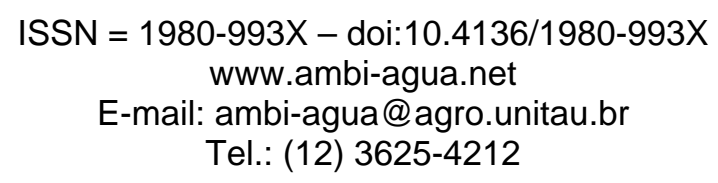

\title{
Mathematical modelling of nutrient balance of a goldfish (Carassius auratus Linn.) recirculating aquaculture system (GRAS)
}

(doi:10.4136/ambi-agua.134)

\section{Mohd Tanveer'; Sudeep Puthravilakom Sadasivan Nair²; Sanjib Moulick³ ${ }^{3}$ Chanchal Kumar Mukherjee ${ }^{4}$}

\author{
Agricultural \& Food Engineering Department, IIT Kharagpur, India - 721302 \\ E-mail: ${ }^{1}$ nobletanveer@gmail.com; ${ }^{2}$ sudeepps83@gmail.com; ${ }^{3}$ smoulick@agfe.iitkgp.ernet.in; \\ ${ }^{4}$ ckm@agfe.iitkgp.ernet.in
}

\begin{abstract}
In the present study, a goldfish (Carassius auratus Linn.) recirculating aquaculture system (GRAS) has been developed. The GRAS consisted of a culture tank, a screen filter and a foam fractionator for removal of particulate and dissolved solids and a trickling filter for conversion of ammonium- and nitrite-nitrogen to relatively harmless nitrate-nitrogen. The culture of goldfish at a stocking density of $1.08 \mathrm{~kg} / \mathrm{m}^{3}$ was continued for a period of two and half months. Based on mass balance analysis of ammonium- and nitrate-nitrogen and assuming the trickling filter to be a plug flow reactor, a model was formulated to determine the necessary recirculation flow rate at different times of culture for maintaining the major nutrients, viz., ammonium- and nitrate-nitrogen below their permissible limits. The model was calibrated and validated using the real time data obtained from the experimental run. The high values of coefficient of determination and low values of root mean square error show the effectiveness of the model.
\end{abstract}

Keywords: Goldfish; recirculating aquaculture system; plug flow reactor.

\section{Modelagem matemática do balanço de nutrientes de um sistema de aquicultura de circulação para o “Goldfish” (Carassius auratus Linn.)}

\section{RESUMO}

No presente estudo, um sistema (GRAS) de recirculação para a aquicultura do "goldfish" (Carassius auratus Linn.) foi desenvolvido. O GRAS foi composto por um tanque de cultura, um filtro de tela com um fracionador de espuma para a remoção de partículas e de sólidos dissolvidos e um filtro biológico para a conversão do nitrogênio na forma de amônio e nitrito para nitrogênio relativamente inofensivo na forma de nitrato. A cultura do "goldfish" em uma densidade de $1,08 \mathrm{~kg} / \mathrm{m}^{3}$ foi mantida por um período de dois meses e meio. Com base na análise do balanço de massa do nitrogênio na forma de amônio e nitrato e assumindo que o filtro biológico funciona como um reator de interrupção de fluxo, um modelo foi formulado para determinar a vazão de recirculação necessária nas diferentes fases da cultura para a manutenção dos principais nutrientes, especialmente, observando-se se o nitrogênio na forma de amônio e de nitrato são mantidos abaixo dos seus limites admissíveis. O modelo foi calibrado e validado com os dados obtidos em tempo real da execução do experimento. Os altos valores do coeficiente de determinação e os baixos valores do erro quadrático médio mostram a eficácia do modelo.

Palavras-chave: Goldfish; sistema de recirculação em aquicultura; reator de fluxo em pistão. 


\section{INTRODUCTION}

Goldfish (Carassius auratus Linn.), a type of coldwater fish, is one of the most common egg layers ornamental species in the world. Due to ever growing demand of goldfish, there is an urgent need to intensify its culture. Like most carps, goldfish excretes a large amount of waste, because it does not have a stomach and only has an intestinal tract, and thus cannot digest an excess of proteins, unlike most tropical fish. Accumulation of this waste to toxic levels can occur in a relatively short period of time leading to fish mortality. Thus, high intensification of goldfish culture necessitates high water exchange, which also leads to pollution of the water bodies due to effluent discharge. Moreover, goldfish culture system requires a constant freshwater source which is generally not available in most of the places and especially in water scarce areas. At present goldfish are being cultured mainly in open or flow-through systems. The introduction of a recirculating aquaculture system (RAS) for intensive culture of goldfish will solve the above mentioned problems. RAS is a production system in which mechanical as well as biological treatment facilitates recycling of the culture water. Recirculating systems have been identified as one of the main research areas in aquaculture. This system of culture reduces water demands and discharges after reconditioning the water (Goldburg and Naylor, 2005). Mostly recirculating systems are designed to replace $5-10 \%$ of the system volume daily with new water so as to prevent the build up of nitrate-nitrogen concentration in the culture tank (Masser et al., 1999). Modelling water quality parameters in RAS gives the real time information about various limiting parameters and their responses at different times. Weatherley (1982) applied a simple dynamic response analysis to a recirculating aquaculture system and concluded that unsteady state predictive methods have significant potential application in the context of aquaculture, subject to further refinement in the modelling of biochemical kinetics and liquid mixing. Further, Weatherly et al. (1993) described the application of process modelling concepts to an intensive recirculating aquaculture system using ACSL. Watten and Sibrell (2006) provided a spreadsheet program for simulating RAS water chemistry using the reactor theory. Wik et al. (2009) developed a model for integrated dynamic aquaculture and wastewater treatment for RAS.

Only few research works have been conducted on goldfish RAS. Ng et al. (1992) evaluated water quality within a recirculating system for tropical ornamental fish culture which included goldfish as one of their species. Further, Ng et al. (1993) provided an approximate estimation for determining metabolic production rates for tropical ornamental fish. Watson and Hill (2006) presented design criteria for recirculating, marine ornamental production systems. The available literatures on goldfish RAS in particular, failed to comment about the carrying capacity of the system, prediction of water quality parameters, sizing of mechanical and biological treatment units and also about the economics of the system.

The objective of the present study is to develop a goldfish recirculating aquaculture system and thereby formulate a mathematical model to determine the necessary recirculating flow rate at different times of culture for maintaining the major nutrients, viz., total ammonia nitrogen and nitrate-nitrogen below their permissible limits.

\section{MATERIALS AND METHODS}

A goldfish RAS was developed consisting of three components: i) culture unit, ii) solid removal unit and iii) nitrogen removal unit. A typical schematic diagram showing all the components as mentioned above is shown in Figure 1. In this section, the details of the 
TANVEER, M.; NAIR, S. P. S.; MOULICK, S.; MUKHERJEE, C. K. Mathematical modelling of nutrient balance of a goldfish (Carassius auratus Linn.) recirculating aquaculture system (GRAS). Ambi-Agua, Taubaté, v. 5, n. 2, p. 30-39, 2010. (doi:10.4136/ambi-agua.134)

individual components are described in brief and the corresponding methodology is listed below.

(i) Culture unit: Culture unit consisted of a $2.5 \times 2 \times 1.4 \mathrm{~m}^{3}$ concrete tank. The water depth was maintained at $1.0 \mathrm{~m}$ making the effective water volume to be $5 \mathrm{~m}^{3}$. Total 1800 Nos. goldfish were stocked in the culture tank with a stocking density of $1.08 \mathrm{~kg} / \mathrm{m}^{3}$ and fed with zooplankton. Diffuser air stones were used for aeration to maintain minimum dissolved oxygen of $6 \mathrm{mg} / \mathrm{L}$ throughout the culture period. Alkalinity was maintained at $50-75 \mathrm{ppm}$ using sodium bicarbonate (Lawson, 1994).

(ii) Solid removal unit: To remove the settleable as well as the suspended solids (size greater than $60-80 \mu \mathrm{m}$ ), a mechanical screen filter of size $70 \times 50 \times 45 \mathrm{~cm}^{3}$ was used in the present study. The main advantage of using screen filter technologies is their small size and relatively low water loss during backwashing. To remove dissolve organic carbon and particulate organic carbon from fish culture water, foam fractionator of acrylic column having length $1.2 \mathrm{~m}$, diameter $9 \mathrm{~cm}$ was adopted based on Chen et al. (1994a, 1994b). It consisted of a cylindrical column on which the wastewater is passed in downward direction and air is injected from the bottom of the chamber which moves in the upward direction. Surface-active particles become attached to these bubbles making the density of the bubble-solid aggregates lower than that of the water. As a result, they rise to the surface in the form of foams which finally with the help of a vacuum pump can be separated from the main stream.

(iii) Nitrogen removal unit: To remove the nitrogenous waste three cylindrical acrylic columns of diameter $90 \mathrm{~mm}$ and height $1800 \mathrm{~mm}$ were fabricated to act as trickling filter. The filter columns were also covered with black paper to prevent the algal growth. A provision for aeration was made at the bottom of the column and a water spraying mechanism was also connected for uniform distribution of effluent over the top surface of the columns. These columns were filled up with nylon pot scrubber media and inoculated with a synthetic substrate containing ammonium chloride, sodium bicarbonate and other necessary nutrients (Zhu and Chen, 2002) for optimum growth of nitrifiers as well as removal of the entire ammonium- and nitrite -nitrogen from the solution.

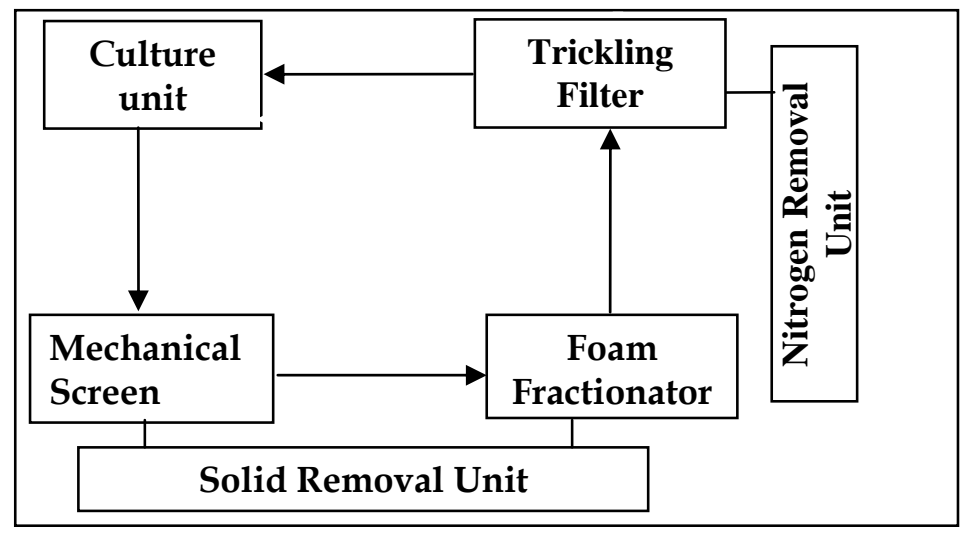

Figure 1. Recirculating aquaculture system showing individual components.

\subsection{Fish growth parameters}

Various fish growth parameters like weight, length, breadth etc were measured periodically and indices like specific growth rate (SGR) and condition factor (K) were found out using the following formulae:

Specific growth rate,

$\operatorname{SGR}\left(\right.$ day $\left.^{-1}\right)=\left(\ln W_{2}-\ln W_{1}\right) /\left(t_{2}-t_{1}\right)$ 
where,

$\mathrm{W}_{1}$, average weight of the fish at time $\mathrm{t}_{1}$ (days)

$\mathrm{W}_{2}$, average weight of the fish at time $\mathrm{t}_{2}$ (days)

Condition factor,

$\mathrm{K}=\mathrm{W} \times 100 / \mathrm{L}^{3}$

where,

W, weight of fish (g), and L, length of fish (cm).

\subsection{Water quality monitoring}

Water samples were collected from the outlets of the different units of the system for measurement of ammonium-, nitrite- and nitrate-nitrogen concentrations using a HACH spectrophotometer (Model R2500) following Standard Methods (APHA et al., 1995). Dissolved oxygen was measured daily by using YSI 55 DO meter.

\subsection{Modeling of temporal variation of flow rates in goldfish recirculating aquaculture system (GRAS)}

A material flow diagram of the GRAS is presented in Figure 2. The symbol C(i) represents the concentration of any water quality parameters (like $\mathrm{NH}_{4}-\mathrm{N}, \mathrm{NO}_{2}-\mathrm{N}, \mathrm{NO}_{3}-\mathrm{N}$ and dissolved oxygen) in the rearing system at any instant ' $i$ '. The water quality parameters are generally dependent on amount of feed fed to the fish. The amount of feed depends on the biomass size, which generally varies with time. Thus the concentration of various water quality parameters varies with time. To maintain the values of the water quality parameters at their desirable limits, recirculating flow rate $\left(\mathrm{Q}_{\mathrm{r}}\right)$ and make-up flow rate $(\mathrm{Q})$ should be varied with time. In the present study a mathematical model was developed to determine the required temporal variation of $\mathrm{Q}_{\mathrm{r}}$ and $\mathrm{Q}$ for maintaining the concentration of various water quality parameters at their desired values. $\mathrm{Q}_{\mathrm{r}}$ mainly depends on $\mathrm{NH}_{4}-\mathrm{N}$ concentration in the culture tank as other parameters are less toxic and can also be maintained by introducing proper solid removal unit and aeration system. On the other hand, Q solely depends on nitrate-N concentration. Thus, in this study a model was developed based on the mass balances of TAN and nitrate-N only.

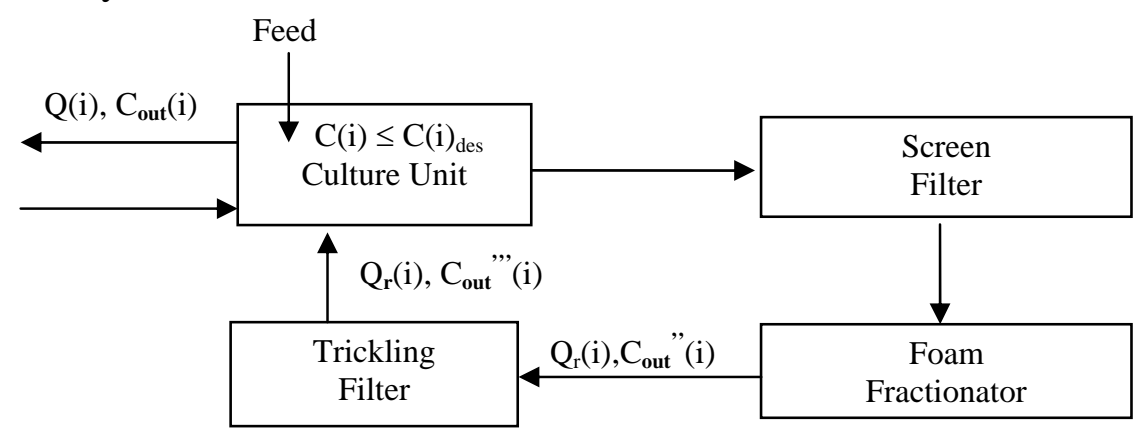

Figure 2. Material flow diagram of the GRAS.

\subsubsection{Modeling of trickling filter using reactor theory}

Assuming the trickling filters perform as a plug flow reactor, the reaction rate constants (i.e., $\mathrm{K}_{1}$ and $\mathrm{K}_{2}$ ) were evaluated using the following equations (Watten and Sibrell, 2006):

$\mathrm{C}_{\mathrm{NH}_{4}-\mathrm{N}_{\text {out }}}=\mathrm{C}_{\mathrm{NH}_{4}-\mathrm{N}_{\text {in }}} \mathrm{e}^{-\mathrm{K}_{1}{ }_{1}}$ 
TANVEER, M.; NAIR, S. P. S.; MOULICK, S.; MUKHERJEE, C. K. Mathematical modelling of nutrient balance of a goldfish (Carassius auratus Linn.) recirculating aquaculture system (GRAS). Ambi-Agua, Taubaté, v. 5, n. 2, p. 30-39, 2010. (doi:10.4136/ambi-agua.134)

$$
\begin{aligned}
& \mathrm{C}_{\mathrm{NO}_{2}-\mathrm{Nout}}=\left[\mathrm{K}_{1}\left[\mathrm{C}_{\mathrm{NH}_{4}-\mathrm{N}_{\mathrm{in}}}\right]\left(\mathrm{e}^{-\mathrm{K}}{ }_{1}{ }^{\mathrm{t}}-\mathrm{e}^{-\mathrm{K}}{ }_{2}{ }^{\mathrm{t}}\right) /\left(\mathrm{K}_{2}-\mathrm{K}_{1}\right)\right]+\mathrm{C}_{\mathrm{NO}_{2}-\mathrm{N}_{\text {in }}} \mathrm{e}^{-\mathrm{K}_{2}{ }_{2}}
\end{aligned}
$$

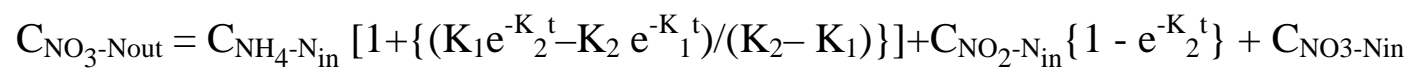

where,

$\mathrm{K}_{1}$ and $\mathrm{K}_{2}$ are the empirically derived first-order reaction rates $\left(\mathrm{T}^{-1}\right)$ that represent the product of a substrate utilization rate constant and the active microbial mass per unit volume of the

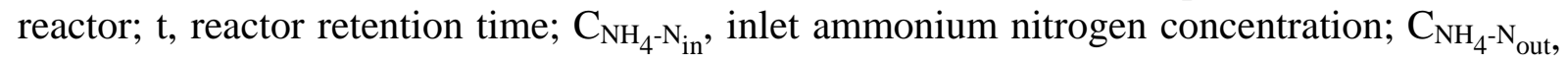
outlet ammonium nitrogen concentration; $\mathrm{C}_{\mathrm{NO}_{2}-\mathrm{N}_{\text {in }}}$, inlet nitrite nitrogen concentration; $\mathrm{C}_{\mathrm{NO}_{2}-}$ $\mathrm{N}_{\text {out }}$, outlet nitrite concentration; $\mathrm{C}_{\mathrm{NO}_{3}-\mathrm{N}_{\text {in }}}$, inlet nitrate nitrogen concentration and $\mathrm{C}_{\mathrm{NO}_{3}-\mathrm{N}_{\text {out }}}$, outlet nitrate nitrogen concentration.

\subsubsection{Ammonium nitrogen mass balance for culture tank}

The culture tank was assumed to be a complete mix reactor. Thus, the concentration of all water quality parameters inside and at the outlet of the culture tank was assumed to remain unchanged. Considering the $\mathrm{NH}_{4}-\mathrm{N}$ mass balance and assuming that $10 \%$ of the produced $\mathrm{NH}_{4}-\mathrm{N}$ undergoes nitrification in the culture unit, the following equation can be written under steady state condition.

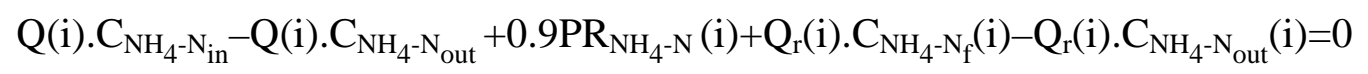

where,

$\mathrm{C}_{\mathrm{NH}_{4}-\mathrm{N}_{\text {in }}}$, TAN concentration in makeup water

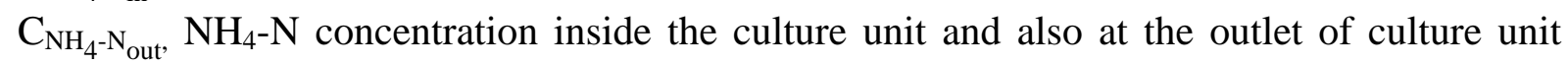
assuming culture unit as the mixed flow reactor

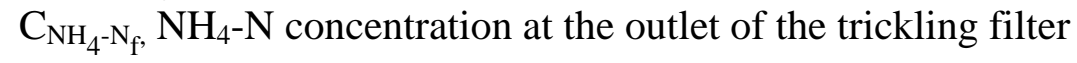

$\mathrm{PR}_{\mathrm{NH}_{4}-\mathrm{N}}, \mathrm{NH}_{4}-\mathrm{N}$ production rate = Biomass $(\mathrm{kg}) \times$ percentage body weight $\times \mathrm{K}_{\mathrm{NH}_{4}-\mathrm{N}}$

$\mathrm{K}_{\mathrm{NH}_{4}-\mathrm{N}}$ represents the amount of production of $\mathrm{NH}_{4}-\mathrm{N}$ per unit weight of feed applied. It varies with biomass size which in turn depends on time. Thus $\mathrm{K}_{\mathrm{NH}_{4}-\mathrm{N}}$ is a function of time.

The value of $\mathrm{C}_{\mathrm{NH}_{4}-\mathrm{N}_{\mathrm{f}}}$ can be determined by using Equation [3].

\subsubsection{Nitrate nitrogen mass balance}

It is depicted from Equation [7] that 1 mole of $\mathrm{NH}_{4}-\mathrm{N}$ produces 1 mole of $\mathrm{NO}_{3}-\mathrm{N}$.

$$
\mathrm{NH}_{4}{ }^{+}+2 \mathrm{O}_{2} \longrightarrow \mathrm{NO}_{2}{ }^{-}+2 \mathrm{H}_{2} \mathrm{O}
$$

Thus, the nitrate-nitrogen mass balance equation at steady state condition can be expressed as follows:

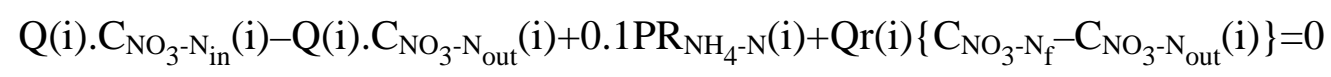

where,

$\mathrm{C}_{\mathrm{NO}_{3}-\mathrm{N}_{\mathrm{f}}}$, nitrate nitrogen concentration at the trickling filter outlet. The value of $\mathrm{C}_{\mathrm{NO}_{3}-\mathrm{N}_{\mathrm{f}}}$ can be found out using Equation [5]. 
TANVEER, M.; NAIR, S. P. S.; MOULICK, S.; MUKHERJEE, C. K. Mathematical modelling of nutrient balance of a goldfish (Carassius auratus Linn.) recirculating aquaculture system (GRAS). Ambi-Agua, Taubaté, v. 5, n. 2, p. 30-39, 2010. (doi:10.4136/ambi-agua.134)

\subsubsection{Model expression for determination of necessary recirculation flow rate $\left(Q_{\mathbf{r}}\right)$}

Rearranging Equation [6] and [8], Q(i) can be expressed as a function of $\mathrm{Q}_{\mathrm{r}}(\mathrm{i})$ and other variables as follows:

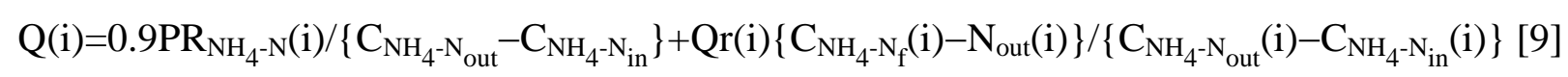

Substituting the value of Q(i) from Equation [9] in Equation [6], we get

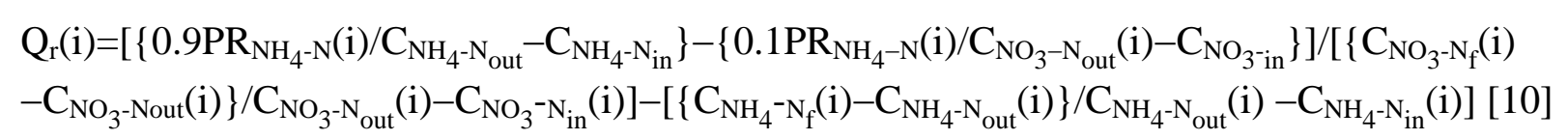

where,

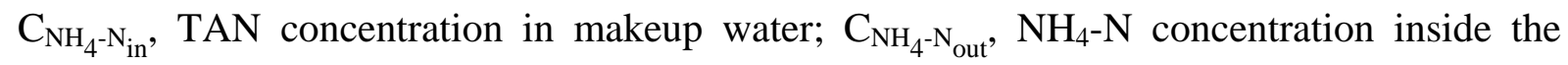
culture unit and also at the outlet of culture unit assuming culture unit as the mixed flow reactor and $\mathrm{C}_{\mathrm{NH}_{4}-\mathrm{N}_{\mathrm{f}}}$, $\mathrm{NH}_{4}-\mathrm{N}$ concentration at the outlet of the trickling filter.

\subsubsection{Model Calibration and Validation}

For calibration of the model, the GRAS was run at different values of $\mathrm{Q}_{\mathrm{r}}$ (3 to $9 \mathrm{~L} / \mathrm{min}$ ) and subsequently the concentrations of various water quality parameters, viz., $\mathrm{NH}_{4}-\mathrm{N}, \mathrm{NO}_{2}-$ $\mathrm{N}$, and $\mathrm{NO}_{3}-\mathrm{N}$ were measured. Expressions for $\mathrm{K}_{\mathrm{NH}_{4}-\mathrm{N}}, \mathrm{K}_{1}$ and $\mathrm{K}_{2}$ were developed in such a way that the square of the differences between the observed and predicted values of $\mathrm{Q}_{r}$ are minimized.

The validation of the model was tested using two criteria: coefficient of determination $\left(R^{2}\right)$ and root mean square error (RMSE). The coefficient of determination $\left(R^{2}\right)$ describes the properties of the total variance in the observed data that could be explained by the model.

$\mathrm{R}^{2}=\left[\Sigma\left(\mathrm{O}_{\mathrm{i}}-\mathrm{O}_{\mathrm{avg}}\right)\left(\mathrm{S}_{\mathrm{i}}-\mathrm{S}_{\mathrm{avg}}\right)\right] /\left[\left\{\Sigma\left(\mathrm{O}_{\mathrm{i}}-\mathrm{O}_{\mathrm{avg}}\right)^{2}\right\}^{0.5}\left\{\Sigma\left(\mathrm{S}_{\mathrm{i}}-\mathrm{S}_{\mathrm{avg}}\right)^{2}\right\}^{0.5}\right]$

where,

$\mathrm{O}_{\mathrm{i}}, \mathrm{i}^{\text {th }}$ observed value; $\mathrm{O}_{\text {avg }}$, mean of the observed values; $\mathrm{S}_{\mathrm{i}}, \mathrm{i}^{\text {th }}$ simulated value;

$\mathrm{S}_{\mathrm{avg}}$, mean of the model simulated values and $\mathrm{N}$, total no of events

Root Mean Square Error (RMSE) of the model can be expressed as follows:

$\operatorname{RMSE}=\left[(1 / \mathrm{N}) \Sigma\left(\mathrm{O}_{\mathrm{i}}-\mathrm{S}_{\mathrm{i}}\right)^{2}\right]^{0.5}$

\section{RESULTS AND DISCUSSION}

The Experimental run was conducted for duration of two and half months (01 October to 15 December, 2008). The temperature of water during the investigation period fluctuated between 18.8 and $24.3^{\circ} \mathrm{C}$, pH values between 7.0 and 8.1 and dissolved oxygen concentrations between 5.7 and $7.1 \mathrm{mg} / \mathrm{L}$.

\subsection{Fish growth parameters}

The specific growth rate (SGR) and condition factor (K) of the fish were determined using Equation [1] and [2] and are presented in Table 1. Further, their variation with time is presented in Figure 3. It can be seen from Table 1 and Figure 3 that both SGR and K decreased with time. This may be attributed to the fact that growth of fish decreases with decrease in temperature. At the starting point of culture (1 October, 2008) the temperature of 
TANVEER, M.; NAIR, S. P. S.; MOULICK, S.; MUKHERJEE, C. K. Mathematical modelling of nutrient balance of a goldfish (Carassius auratus Linn.) recirculating aquaculture system (GRAS). Ambi-Agua, Taubaté, v. 5, n. 2, p. 30-39, 2010. (doi:10.4136/ambi-agua.134)

water was around $24.3^{\circ} \mathrm{C}$, however it decreased up to $18.8^{\circ} \mathrm{C}$ at the end of the culture (15 December, 2008). The values of $\mathrm{K}$ were found to be always greater than 1.0, implying that the fish were fed adequately.

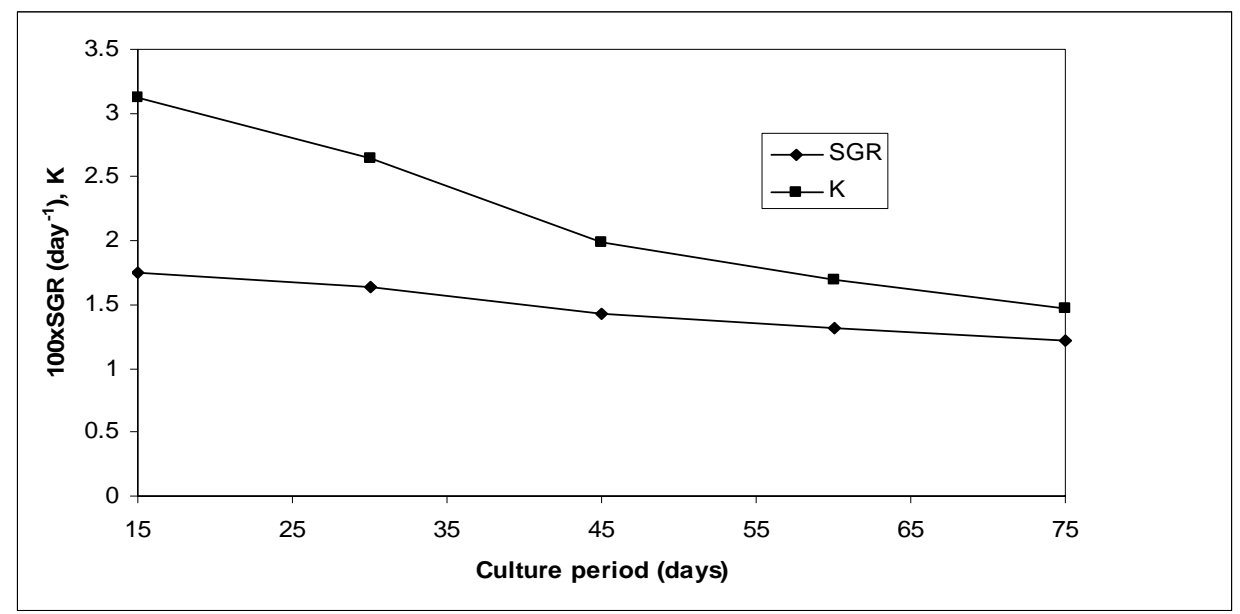

Figure 3. Variation of specific growth rate (SGR) and condition factor (K) of goldfish with time.

Table 1. Fish growth parameters.

\begin{tabular}{cccccc}
\hline $\begin{array}{c}\text { Time } \\
\text { (days) }\end{array}$ & $\begin{array}{c}\text { Average } \\
\text { Weight } \\
\text { (g) }\end{array}$ & $\begin{array}{c}\text { Average } \\
\text { Length } \\
(\mathbf{c m})\end{array}$ & $\begin{array}{c}\text { Temperature } \\
\left(\mathbf{(}^{\mathbf{0}} \mathbf{C}\right)\end{array}$ & $\begin{array}{c}\mathbf{1 0 0} \times \text { Specific } \\
\text { growth rate } \\
\text { (SGR) } \\
\left(\text { day }^{-\mathbf{1}}\right)\end{array}$ & $\begin{array}{c}\text { Condition factor } \\
(\mathbf{K})\end{array}$ \\
\hline 0 & 3 & 4.3 & 24.3 & --- & -- \\
15 & 3.9 & 5.0 & 23.8 & 1.75 & 3.12 \\
30 & 4.9 & 5.7 & 22.0 & 1.64 & 2.65 \\
45 & 5.7 & 6.6 & 21.0 & 1.43 & 1.98 \\
60 & 6.6 & 7.3 & 19.6 & 1.31 & 1.70 \\
75 & 7.5 & 8.0 & 18.8 & 1.22 & 1.46 \\
\hline
\end{tabular}

\subsection{Development of Mathematical Model for GRAS}

\subsubsection{Calibration of the model}

Based on the ammonium- and nitrate-nitrogen mass balance, a mathematical model was developed (Equations 3 - 10). The model was calibrated by operating the GRAS at different flow rates ranging from $3 \mathrm{~L} / \mathrm{min}$ to $6.5 \mathrm{~L} / \mathrm{min}$. The observed concentrations of $\mathrm{NH}_{4}-\mathrm{N}, \mathrm{NO}_{2}-\mathrm{N}$ and $\mathrm{NO}_{3}-\mathrm{N}$ at various points are presented in Table 2 . The abbreviations for foam fractionator and trickling filter are denoted as FF and TF respectively as can be seen in the above table. Based on the above data and using Equations $3-10$, the expressions for $\mathrm{K} 1$ and $\mathrm{K}_{\mathrm{NH}_{4}-\mathrm{N}}$ were deduced. $\mathrm{K}_{1}$ was found to be a function of inlet $\mathrm{NH}_{4}-\mathrm{N}$ and $\mathrm{Q}_{\mathrm{r}}$.

$$
\begin{gathered}
\mathrm{K}_{1}=-2.69 \times \text { inlet } \mathrm{NH}_{4}-\mathrm{N}-\left[0.17 \mathrm{E}-12 /\left(\text { inlet } \mathrm{NH}_{4}-\mathrm{N}\right)^{3}\right]+16.64 \times \mathrm{Q}_{\mathrm{r}}-0.34 \mathrm{E}-05 \times \ln \left(\mathrm{Q}_{\mathrm{r}}\right)^{3} \\
\left(\mathrm{R}^{2}=0.98\right)
\end{gathered}
$$

On the other hand, $\mathrm{K}_{\mathrm{NH}_{4}-\mathrm{N}}$ values were found to have a linear correlation with culture time in days. The equation representing the variation of $\mathrm{K}_{\mathrm{NH}_{4}-\mathrm{N}}$ with time is as follows:

$\mathrm{K}_{\mathrm{NH}_{4}-\mathrm{N}}=0.3206 \times($ time in days $)-16.465$

$$
\left(\mathrm{R}^{2}=0.97\right)
$$


TANVEER, M.; NAIR, S. P. S.; MOULICK, S.; MUKHERJEE, C. K. Mathematical modelling of nutrient balance of a goldfish (Carassius auratus Linn.) recirculating aquaculture system (GRAS). Ambi-Agua, Taubaté, v. 5, n. 2, p. 30-39, 2010. (doi:10.4136/ambi-agua.134)

In all the cases, the parameter $\mathrm{K}_{2}$ was found to be an insensitive one. It was assigned a value of $0.3 \mathrm{~s}^{-1}$ based on the values obtained during performance evaluation of trickling filters.

Equation [13] and [14] are valid subject to $63 \leq$ time of culture (days) $\leq 70$.

Table 2. Observed values of $\mathrm{NH}_{4}-\mathrm{N}, \mathrm{NO}_{2}-\mathrm{N}$ and $\mathrm{NO}_{3}-\mathrm{N}$ concentrations at different sampling points.

\begin{tabular}{|c|c|c|c|c|}
\hline $\begin{array}{c}\text { Flow rate } \\
\left(Q_{r}(\mathbf{i})\right)(L / m i n)\end{array}$ & Sampling point & $\begin{array}{l}\mathrm{NH}_{4}-\mathrm{N} \\
(\mathrm{mg} / \mathrm{L})\end{array}$ & $\begin{array}{l}\mathrm{NO}_{2}-\mathrm{N} \\
(\mathrm{mg} / \mathrm{L})\end{array}$ & $\begin{array}{l}\mathrm{NO}_{3}-\mathrm{N} \\
(\mathrm{mg} / \mathrm{L})\end{array}$ \\
\hline \multirow{3}{*}{3.00} & Culture tank & 0.55 & 0.029 & 7.7 \\
\hline & $*$ FF outlet & 0.36 & 0.029 & 7.7 \\
\hline & $* *$ TF outlet & 0.20 & 0.021 & 7.9 \\
\hline \multirow{3}{*}{3.5} & Culture tank & 0.58 & 0.028 & 8.3 \\
\hline & FF outlet & 0.41 & 0.027 & 8.2 \\
\hline & TF outlet & 0.24 & 0.02 & 8.5 \\
\hline \multirow{3}{*}{4.0} & Culture tank & 0.60 & 0.035 & 8.9 \\
\hline & FF outlet & 0.43 & 0.035 & 8.8 \\
\hline & TF outlet & 0.25 & 0.022 & 9.1 \\
\hline \multirow{3}{*}{4.5} & Culture tank & 0.60 & 0.039 & 11.2 \\
\hline & FF outlet & 0.54 & 0.04 & 11.3 \\
\hline & TF outlet & 0.29 & 0.028 & 11.5 \\
\hline \multirow{3}{*}{5.0} & Culture tank & 0.62 & 0.043 & 13.5 \\
\hline & FF outlet & 0.63 & 0.043 & 13.3 \\
\hline & TF outlet & 0.32 & 0.031 & 13.7 \\
\hline \multirow{3}{*}{5.5} & Culture tank & 0.65 & 0.046 & 14.5 \\
\hline & FF outlet & 0.64 & 0.047 & 14.6 \\
\hline & TF outlet & 0.33 & 0.034 & 14.8 \\
\hline \multirow{3}{*}{6.0} & Culture tank & 0.68 & 0.038 & 14.5 \\
\hline & FF outlet & 0.65 & 0.034 & 14.6 \\
\hline & TF outlet & 0.37 & 0.019 & 14.9 \\
\hline \multirow{3}{*}{6.5} & Culture tank & 0.72 & 0.059 & 16.1 \\
\hline & FF outlet & 0.78 & 0.057 & 16.2 \\
\hline & TF outlet & 0.41 & 0.039 & 16.5 \\
\hline
\end{tabular}

${ }^{*} \mathrm{FF}=$ foam fractionator and ${ }^{* *} \mathrm{TF}=$ trickling filter

\subsubsection{Validation of the model}

After the calibration, the model was validated with data obtained from the experiments conducted from the $71^{\text {st }}$ day to $75^{\text {th }}$ day at different flow rates varying from 7.0 to $9.0 \mathrm{~L} / \mathrm{min}$

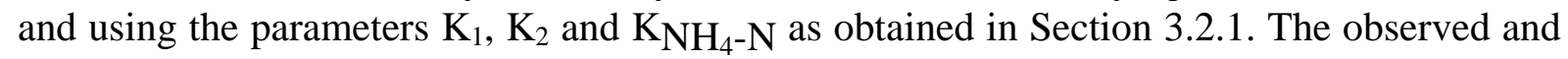
predicted values of $\mathrm{Q}_{\mathrm{r}}, \mathrm{NH}_{4}-\mathrm{N}_{\mathrm{f}}$ and $\mathrm{NO}_{3}-\mathrm{N}_{\mathrm{f}}$ are presented in Table 3. The values of coefficient of determination $\left(\mathrm{R}^{2}\right)$ and root mean square error (RMSE) for $\mathrm{Q}_{\mathrm{r}}, \mathrm{NH}_{4}-\mathrm{N}_{\mathrm{f}}$ and $\mathrm{NO}_{3}-\mathrm{N}_{\mathrm{f}}$ are presented in Table 4 . The high values of $\mathrm{R}^{2}$ and low values of RMSE show the effectiveness of the model. 
TANVEER, M.; NAIR, S. P. S.; MOULICK, S.; MUKHERJEE, C. K. Mathematical modelling of nutrient balance of a goldfish (Carassius auratus Linn.) recirculating aquaculture system (GRAS). Ambi-Agua, Taubaté, v. 5, n. 2, p. 30-39, 2010. (doi:10.4136/ambi-agua.134)

Table 3. Observed and predicted values of $\mathrm{Q}_{\mathrm{r}}, \mathrm{NH}_{4}-\mathrm{N}_{\mathrm{f}}$ and $\mathrm{NO}_{3}-\mathrm{N}_{\mathrm{f}}$.

\begin{tabular}{c|c|c|c|c|c|c|c|c}
\hline $\begin{array}{c}\text { Time } \\
\text { (days) }\end{array}$ & $\begin{array}{c}\mathbf{Q}_{\mathbf{r}}(\mathbf{i}) \\
\text { Observed } \\
(\mathbf{L} / \mathbf{m i n})\end{array}$ & $\begin{array}{c}\mathbf{Q}_{\mathbf{r}}(\mathbf{i}) \\
\text { Predicted } \\
(\mathbf{L} / \mathbf{m i n})\end{array}$ & $\begin{array}{c}\mathbf{K}_{1} \\
\left.\mathbf{( s}^{-1}\right) \\
\times \mathbf{1 0}^{3}\end{array}$ & $\begin{array}{c}\mathbf{K}_{2} \\
\left.\mathbf{s}^{-1}\right)\end{array}$ & $\begin{array}{c}\mathbf{C}_{\mathrm{NH}_{4}-\mathrm{Nf}} \\
\text { Observed } \\
(\mathbf{m g} / \mathbf{L})\end{array}$ & $\begin{array}{c}\mathbf{C}_{\mathrm{NH}_{4}-\mathrm{Nf}} \\
\text { Predicted } \\
(\mathbf{m g} / \mathbf{L})\end{array}$ & $\begin{array}{c}\mathbf{C}_{\mathrm{NO}_{3}-\mathrm{Nf}} \\
\text { Observed } \\
(\mathbf{m g} / \mathbf{L})\end{array}$ & $\begin{array}{c}\mathbf{C}_{\mathrm{NO}_{3}-\mathrm{Nf}} \\
\text { Predicted } \\
(\mathbf{m g} / \mathbf{L})\end{array}$ \\
\hline 71 & 7.0 & 6.78 & 2.08 & 0.3 & 0.43 & 0.42 & 17.5 & 17.4 \\
72 & 7.5 & 7.14 & 2.14 & & 0.46 & 0.45 & 17.7 & 17.7 \\
73 & 8.0 & 7.44 & 2.19 & & 0.49 & 0.47 & 17.9 & 18.0 \\
74 & 8.5 & 7.98 & 2.29 & & 0.49 & 0.47 & 18.1 & 18.1 \\
75 & 9.0 & 8.4 & 2.37 & & 0.56 & 0.48 & 18.5 & 18.6 \\
\hline
\end{tabular}

Table 4. Values of coefficient of determination $\left(\mathrm{R}^{2}\right)$ and root mean square error (RMSE) for $\mathrm{Q}_{\mathrm{r}}, \mathrm{NH}_{4}-\mathrm{N}_{\mathrm{f}}$ and $\mathrm{NO}_{3}-\mathrm{N}_{\mathrm{f}}$.

\begin{tabular}{ccc}
\hline Variables & $\mathbf{R}^{2}$ & RMSE \\
\hline $\mathrm{Q}_{\mathrm{r}}$ & 0.995 & $0.22 \mathrm{~L} / \mathrm{min}$ \\
$\mathrm{NH}_{4}-\mathrm{N}_{\mathrm{f}}$ & 0.881 & $0.02 \mathrm{mg} / \mathrm{L}$ \\
$\mathrm{NO}_{3}-\mathrm{N}_{\mathrm{f}}$ & 0.992 & $0.04 \mathrm{mg} / \mathrm{L}$ \\
\hline
\end{tabular}

\section{CONCLUSION}

Based on mass balance analysis of total ammonia nitrogen (TAN) and nitrate-nitrogen $\left(\mathrm{NO}_{3}-\mathrm{N}\right)$, a mathematical model for goldfish recirculating aquaculture system (GRAS) was developed for determination of the necessary flow rates at different times to maintain the various pollutants below their desired level. Subsequently the model could predict the concentration of major water quality parameters like $\mathrm{NH}_{4}-\mathrm{N}$ and $\mathrm{NO}_{3}-\mathrm{N}$ in the GRAS. The model was calibrated by operating the GRAS at different flow rates ranging from 3.0 to 6.5 $\mathrm{L} /$ min. Expressions for determination of $\mathrm{K}_{1}$ and $\mathrm{K}_{\mathrm{NH}_{4}-\mathrm{N}}$ were developed. After the calibration, the model was validated with data obtained from the experiments conducted from the $71^{\text {st }}$ day to $75^{\text {th }}$ day at different flow rates varying from 7.0 to $9.0 \mathrm{~L} / \mathrm{min}$ and using the

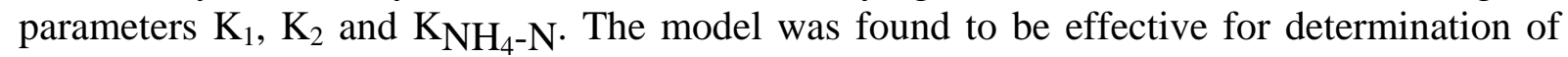
necessary recirculating flow rate and the inorganic nitrogenous compounds in the culture water specifically for GRAS.

\section{REFERENCES}

AMERICAN PUBLIC HEALTH ASSOCIATION; AMERICAN WATER WORKS ASSOCIATION; WATER POLUTION CONTROL FACILITY - APHA, AWWA, WPCF. Standard methods for the examination of water and wastewater. 19. ed. Washington, DC: 1995. 20005 p.

CHEN, S.; TIMMONS, M. B.; BISOGNI JR., J. J.; ANESHANSLEY, D. J. Modeling surfactant removal in foam fractionation: I - theoretical development. Aquacultural Engineering, v. 13, n. 3, p. 163-181, 1994a.

CHEN, S.; TIMMONS, M. B.; BISOGNI JR., J. J.; ANESHANSLEY, D. J. Modeling surfactant removal in foam fractionation: II - experimental investigations. Aquacultural Engineering, v. 13, n. 3, p. 183-200, 1994b. 
TANVEER, M.; NAIR, S. P. S.; MOULICK, S.; MUKHERJEE, C. K. Mathematical modelling of nutrient balance of a goldfish (Carassius auratus Linn.) recirculating aquaculture system (GRAS). Ambi-Agua, Taubaté, v. 5, n. 2, p. 30-39, 2010. (doi:10.4136/ambi-agua.134)

GOLDBURG, R.; NAYLOR, R. Future seascapes, fishing and fish farm farming: a review. Front Ecological Environment, Ocean Farming, v. 3, n.1, p. 21-28, 2005.

LAWSON, T. B. Fundamentals of aquacultural engineering. New York: Chapmann and Hall, 1994.

MASSER, M. P.; RAKOCY, J.; LOSORDO, T. M. Recirculating aquaculture tank production systems: management of recirculating systems. SRAC Publication, v. 452, p 1-12, 1999.

NG, W. J.; KHO, K.; HO, L. M.; ONG, S. L.; SIM, T. S.; TAY, S. H. et al. Water quality within a recirculating system for tropical ornamental fish culture. Aquaculture, v. 103, n. 2, p. 123-134, 1992.

NG, W. J.; KHO, K.; ONG, S. L.; SIM, T. S.; HO, J. M.; TAY, S. H. Preliminary estimation of tropical ornamental fish metabolite production rates. Aquaculture, v. 110, n. 3/4, p. 263- 269, 1993.

WATSON, C. A.; HILL, J. E. Design criteria for recirculating marine ornamental production systems. Aquacultural Engineering, v. 34, n. 3, p. 157-162, 2006.

WATTEN, B. J.; SIBRELL, P. L. Comparative performance of fixed-film biological filters: application of reactor theory. Aquacultural Engineering, v. 34, n. 3, p. 198-213, 2006.

WEATHERLEY, L. R. Application of simple dynamic response analysis to a recirculating aquaculture system - a preview. Aquacultural Engineering, v. 1, n. 2, p. 93-113, 1982.

WEATHERLEY, L. R.; HILL, R. G.; MACMILLAN, K. J. Process modelling of an intensive aquaculture system. Aquacultural Engineering, v. 12, n. 4, p. 215- 230, 1993.

WIK, T. E. I.; BJÖRN, T. L.; PER, I. W. Integrated dynamic aquaculture and wastewater treatment modelling for recirculating aquaculture systems. Aquaculture, v. 287, n. 3-4, p. 361-370, 2009. doi:10.1016/j.aquaculture.2008.10.056.

ZHU, S.; CHEN, S. Effect of organic carbon on nitrification rate in fixed biofilm filters. Aquacultural Engineering, v. 25, n. 1, p. 1- 11, 2002. 